\title{
Inflammatory mediators in intra-abdominal sepsis or injury - a scoping review
}

\author{
Zhengwen Xiao ${ }^{1}$, Crystal Wilson ${ }^{1}$, Helen Lee Robertson ${ }^{2}$, Derek J. Roberts ${ }^{3,4}$, Chad G. Ball ${ }^{1,3}$, Craig N. Jenne ${ }^{5,6}$
} and Andrew W. Kirkpatrick ${ }^{1,3,5^{*}}$

\begin{abstract}
Introduction: Inflammatory and protein mediators (cytokine, chemokine, acute phase proteins) play an important, but still not completely understood, role in the morbidity and mortality of intra-abdominal sepsis/injury. We therefore systematically reviewed preclinical and clinical studies of mediators in intra-abdominal sepsis/injury in order to evaluate their ability to: (1) function as diagnostic/prognostic biomarkers; (2) serve as therapeutic targets; and (3) illuminate the pathogenesis mechanisms of sepsis or injury-related organ dysfunction.
\end{abstract}

Methods: We searched MEDLINE, PubMed, EMBASE and the Cochrane Library. Two investigators independently reviewed all identified abstracts and selected articles for full-text review. We included original studies assessing mediators in intra-abdominal sepsis/injury.

Results: Among 2437 citations, we selected 182 studies in the scoping review, including 79 preclinical and 103 clinical studies. Serum procalcitonin and C-reactive protein appear to be useful to rule out infection or monitor therapy; however, the diagnostic and prognostic value of mediators for complications/outcomes of sepsis or injury remains to be established. Peritoneal mediator levels are substantially higher than systemic levels after intra-abdominal infection/trauma. Common limitations of current studies included small sample sizes and lack of uniformity in study design and outcome measures. To date, targeted therapies against mediators remain experimental.

Conclusions: Whereas preclinical data suggests mediators play a critical role in intra-abdominal sepsis or injury, there is no consensus on the clinical use of mediators in diagnosing or managing intra-abdominal sepsis or injury. Measurement of peritoneal mediators should be further investigated as a more sensitive determinant of intra-abdominal inflammatory response. High-quality clinical trials are needed to better understand the role of inflammatory mediators.

\section{Introduction}

Sepsis is a syndrome that results from the interactions between the host and insults (pathogen, injury) leading to the production/release of biochemical mediators and the triggering of inflammatory cascades [1]. Tissue damage and shock lead to the extracellular release of damageassociated molecular patterns (DAMPs), which evoke a systemic inflammatory response syndrome (SIRS) and hypoxia, reduce resistance to infection, and increase risk

\footnotetext{
* Correspondence: Andrew.Kirkpatrick@albertahealthservices.ca

${ }^{1}$ Regional Trauma Services, Foothills Medical Centre, 1403 - 29 Street NW,

T2N 2T9 Calgary, AB, Canada

${ }^{3}$ Department of Surgery, Foothills Medical Centre, University of Calgary,

1403 - 29 Street NW, T2N 2T9 Calgary, AB, Canada

Full list of author information is available at the end of the article
}

of sepsis [2-4]. Moreover, microbial infection produces pathogen-associated molecular patterns (PAMPs) that drive septic inflammation. DAMPs and PAMPs share a number of conserved families of pattern recognition receptors (PRRs) including the prototypical PRR family, the Toll-like receptors (TLRs). Activation of TLRs on immune cells and endothelial cells leads to the release of pro- and anti-inflammatory mediators, which trigger excessive inflammation, sepsis and multiple organ failure (MOF) $[5,6]$. Intra-abdominal infection and injury are common causes of sepsis in surgical intensive care unit (ICU) patients, with high rates of mortality [7-9]. Early diagnosis and treatment of infection in this group of patients is associated with improved outcome and reduced mortality. However, the clinical definitions of sepsis are nonspecific 
and often result in delay in diagnosis and therapy. One of the most challenging obstacles to the treatment of intraabdominal infection and injury has been establishing the diagnosis and differentiating sepsis with bacterial infection from "sterile" SIRS [10].

Given that both intra-abdominal infection and injury can incite hyperinflammatory status and sepsis, and the inflammatory response to injury is often clinically indistinguishable from sepsis, many studies have sought to identify biomarkers or mediators to aid in the diagnosis and management of sepsis $[11,12]$. The purpose of this scoping review was therefore to systematically review preclinical and clinical studies of inflammatory mediators in abdominal sepsis and injury in order to evaluate their ability to: (1) provide earlier diagnosis of SIRS, sepsis or severe sepsis, or predict complications or outcomes; (2) serve as therapeutic targets for randomized controlled trials (RCTs); (3) illuminate the mechanisms of pathogenesis of sepsis or injury-related organ dysfunction.

\section{Methods}

We developed a protocol according to the Arksey and O'Malley methodological framework for conducting scoping reviews with modifications [13]. Scoping reviews entail the systematic selection, collection and summarization of existing knowledge in a broad thematic area for the purpose of identifying if there is sufficient evidence to conduct a full synthesis or further research is needed. Contrary to systematic reviews, in scoping reviews authors do not typically assess the quality of included studies or perform a meta-analysis [13].

\section{Search strategy}

Two investigators (ZX, AWK) created a preliminary search strategy that was subsequently refined by a medical librarian with extensive systematic review experience (HLR). Relevant articles were identified by searching the following databases from the first date available until August 2014: Ovid MEDLINE; Ovid EMBASE; PubMed; Cochrane Database of Systematic Reviews, and Cochrane Central Register of Controlled Trials. Combinations of the following search terms were used (see Table S1 in Additional file 1 for detailed search strategies): abdominal injuries, intraabdominal inflammation, intraabdominal sepsis, intraabdominal infections, intraabdominal hypertension, peritonitis, sepsis, septic shock, systemic inflammatory response syndrome, bacteremia, multiple organ failure, inflammation mediator, cytokine, interleukin, and biological markers. Appropriate wildcards were used in all searches to account for plural words and variations in spelling. Additional articles were identified by manually searching the bibliographies of those articles identified in the searches until December 2014.

\section{Article selection}

Two investigators ( $\mathrm{ZX}, \mathrm{CW})$ independently screened the titles and abstracts of all identified citations. We included all articles that were original studies (controlled trials, cohort study, case series, case-control) assessing inflammatory or protein mediators in intra-abdominal sepsis or injury. Participants included patients (10 or more) admitted for surgery with peritonitis or abdominal injury, or animal models of abdominal sepsis/injury. Participants required measurement of mediator(s) from blood and/or peritoneal fluid for inclusion. Articles were excluded if not reporting original data, such as reviews, letters, and conference abstracts (no full text available). Disagreements between the two assessors were resolved by consensus.

\section{Article review, data charting and reporting}

The full texts of the remaining articles were independently reviewed by the same two authors. The two investigators extracted data independently using a predesigned electronic data extraction form. Assessors were not blinded to author or journal name [14]. We extracted the following data from included studies: (1) study design and setting; (2) study participant characteristics, including age, primary patient diagnosis (for example, trauma, intra-abdominal sepsis, or source of infection), and severity of illness (for example, acute physiology and chronic health evaluation II (APACHE II) [15], sequential organ failure assessment (SOFA) [16], and injury severity score (ISS) [17]; (3) severity of sepsis [10]; (4) the number of participants, and intervention groups; (5) details of animal models; (6) details of reported mediators; and (7) the outcomes.

Results were first mapped based on their characteristics, such as study design, sample size, preclinical or clinical studies. Owing to the significant variability in study design, sample size, analytical technique and outcome measures, it was impossible to perform a full synthesis analysis of the findings. Therefore, studies were presented in tables based on thematic characteristics of the articles. In addition, the level of evidence for a mediator as a biomarker was discussed based on the "best-evidence synthesis" guideline used in review studies (see Table S2 in Additional file 2) [18].

\section{Risk of bias assessment}

Risk of bias of clinical controlled studies was assessed using the guidelines proposed by the Cochrane Collaboration Back Review Group [19, 20]. These guidelines assist in evaluating study patient participation and treatment allocation, outcome, and confounding factor measurement. 


\section{Results}

The literature search identified 2412 studies (after duplicates removed) and the search from reference lists identified an additional 25 articles. The review of abstracts led to retrieval of 333 full-text articles for assessment. We selected 182 articles for inclusion of this review (Fig. 1).

\section{Characteristics of the articles}

Table 1 summarizes the characteristics of the articles on mediators in intra-abdominal sepsis or injury. Most articles were published in the last two decades (92\%). There were 103 clinical studies (57\%) and 79 preclinical studies (43\%). Among the clinical studies, 63 articles reported mediators as biomarkers for diagnosis on or predicting outcomes of intra-abdominal sepsis; 23 articles described the kinetic change of mediators in intra-abdominal sepsis or injury; and eight were mechanistic studies. Only nine intervention studies with moderate methodological quality were identified concerning intra-abdominal sepsis management. Of the 79 preclinical studies, rodent models and porcine models were the most common animal models used.

\section{Description of the studies and mediators}

Table S3 in Additional file 3 summarizes the clinical studies of mediators as biomarkers in diagnosing infection or predicting outcomes of intra-abdominal sepsis and injuries. Studies of perioperative kinetic changes of mediators are also included in this table. In general, before 1992, Creactive protein $(\mathrm{CRP})$ was the most common mediator studied [21-26]. Thereafter, interleukins (IL-6, -8, -10) and tumor necrosis factor alpha (TNF- $\alpha$ ) were on the top list of the reported mediators [27-106]. Since 2000, procalcitonin (PCT) was often examined as a clinically promising biomarker $[49,57,64,66,74,77,78,88,93,95$, $100,101,106]$. Notably PCT was the only biomarker being explored through randomized-type designs. More recently, DAMPs and endothelial dysfunction molecules had been added to the ever-growing list of mediators [3, 63, 80, 82, 84, 85, 91, 99, 105].

\section{C-reactive protein}

There have been 33 studies exploring CRP as a marker for abdominal infection or complications after surgery
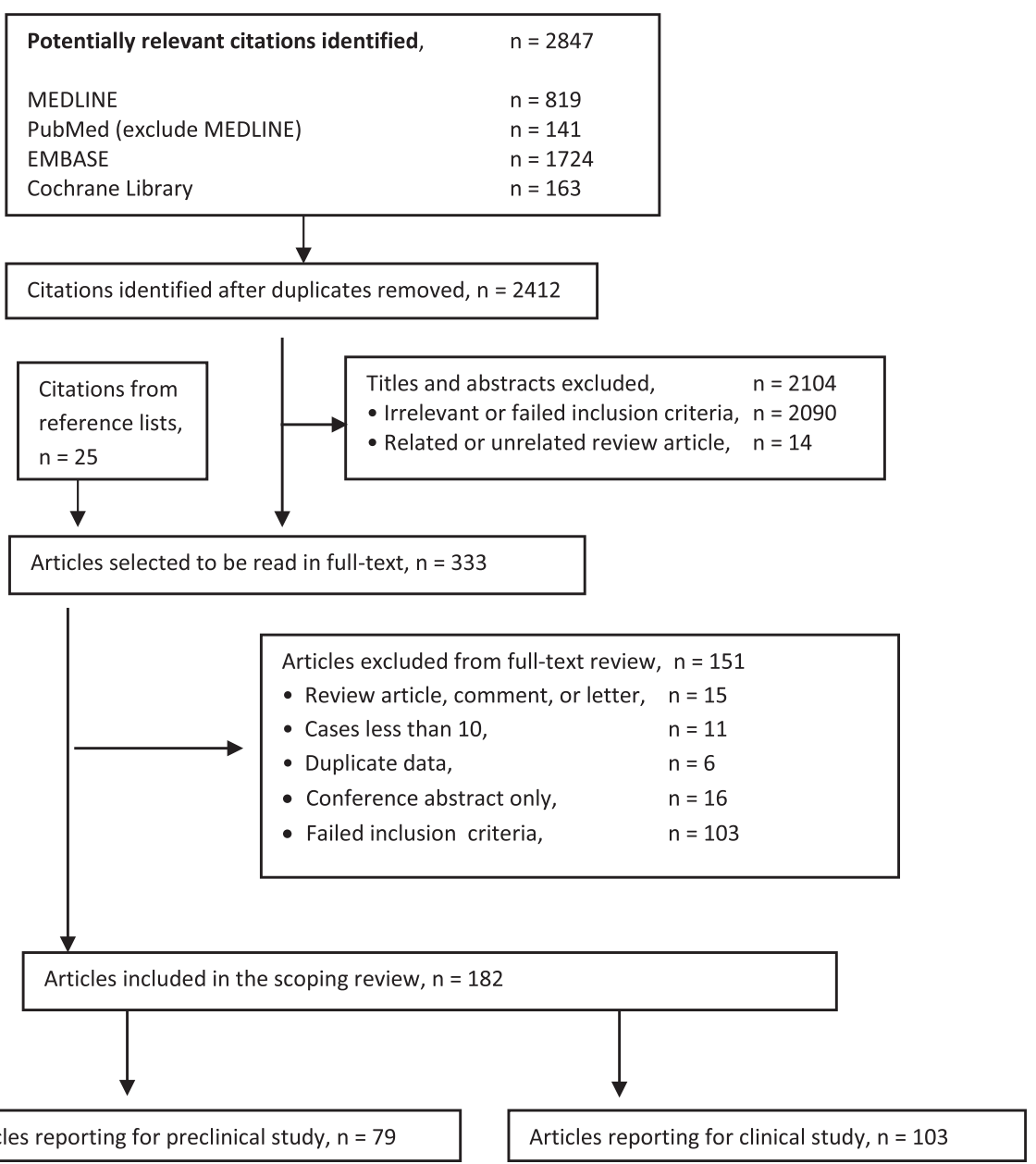

Fig. 1 Flow chart of steps for study selection 
Table 1 Characteristics of articles on inflammatory/protein mediators in intra-abdominal sepsis or injury

\begin{tabular}{|c|c|}
\hline Characteristics & Number (\%) of 182 articles \\
\hline \multicolumn{2}{|l|}{ Type of article } \\
\hline Clinical study & $103(57 \%)$ \\
\hline Biomarker or diagnosis study & $63(35 \%)$ \\
\hline Intervention study & $9(5 \%)$ \\
\hline Mechanistic or kinetic study & $31(17 \%)$ \\
\hline \multicolumn{2}{|l|}{ Study design } \\
\hline Randomized controlled trials & 4 \\
\hline Nonrandomized controlled trials & 5 \\
\hline Cohort study & 36 \\
\hline Case-control study & 29 \\
\hline Case series & 29 \\
\hline Abdominal sepsis & 64 \\
\hline Abdominal injury or ischemia-reperfusion & 27 \\
\hline Mixed sepsis and injury & 12 \\
\hline Preclinical study & $79(43 \%)$ \\
\hline Intervention study & $32(17 \%)$ \\
\hline Mechanistic study & $47(26 \%)$ \\
\hline \multicolumn{2}{|l|}{ Study design } \\
\hline Rodent model & 69 \\
\hline Porcine model & 7 \\
\hline Canine model & 1 \\
\hline Rabbit model & 1 \\
\hline Baboon model & 1 \\
\hline Injury or ischemia-reperfusion & 26 \\
\hline Abdominal sepsis & 44 \\
\hline Mixed injury and sepsis & 9 \\
\hline \multicolumn{2}{|l|}{ Year of publication } \\
\hline 1985-1994 & $14(8 \%)$ \\
\hline 1995-2004 & $65(35 \%)$ \\
\hline $2005-2014$ & $103(57 \%)$ \\
\hline \multicolumn{2}{|l|}{ Country of origin } \\
\hline European countries & $80(44 \%)$ \\
\hline United States of America & $44(24 \%$ \\
\hline Other countries & $58(32 \%)$ \\
\hline
\end{tabular}

$[21,22,24-27,29,32,34,39,47,49,51-53,57,61,64$, $66,68,70,79,86-88,90,92,95,96,98,100,103,106]$. Kinetics studies demonstrated that serum CRP levels begun to elevate on postoperative day 1 (POD1), peaked from POD2 to POD3 (approximately 12-24 hours after peak levels of IL-6), and then declined to baseline levels on POD5 providing there was no complication or infection after major abdominal surgery $[29,39,52,53,57$, 79, 90, 96]. Four reports suggested that persistent levels of more than $100 \mathrm{mg} / \mathrm{l}$ after POD5 indicate abscess formation or other septic complications (e.g., anastomotic leakage) [21, 92, 98, 103]. Mustard et al. reported an accuracy of $75 \%$ for detecting infection when CRP was greater than $15 \mathrm{mg} / \mathrm{l}$ after POD4 [24]. However, other studies reported a limited role for CRP to diagnose sepsis or predict outcomes in other clinical scenarios $[34,49,51,64,87,88,96]$.

\section{Procalcitonin}

Twelve trials (including two randomized controlled studies) explored PCT as an indicator to diagnose infection, predict outcomes, or guide treatment of abdominal 
sepsis or injury $[49,57,64,66,74,77,78,88,93,95$, $100,101]$. Serum PCT increased immediately after surgical injury, peaked on POD1, and declined to half its peak level from POD2 to POD3 after uncomplicated major abdominal surgery [57, 66, 77, 100]. Reith et al. performed a large case-control study of 246 patients with abdominal sepsis [49]. The results from this study suggested that serum PCT appeared to be a good predictor of severity and mortality. A reduction of serum PCT on POD1 to POD4 correlated with improvement in sepsis [49]. Similar findings were reported by Mokart et al. leading to the suggestion that a cutoff value of $1.1 \mathrm{ng} / \mathrm{ml}$ serum PCT on POD1 was a good predictor of subsequent sepsis in patients undergoing major surgery [64]. Four studies suggested that PCT clearance kinetics appear to be a better indicator than a single cutoff value to diagnose septic complications or predict outcomes. Persistently high PCT in plasma was associated with infection or with a significant increase in mortality in patients with sepsis in those studies [77, 88, 93, 95]. Therefore, PCT had been used as a guide for imaging or interventions, or antibiotic therapy for patients with abdominal sepsis [74, 78]. Importantly however, other studies have not consistently confirmed PCT as an accurate marker for sepsis or to predict patient's response to the initial treatment $[100,101]$.

\section{Interleukin-6}

Fifty-five of 86 studies examined IL-6, alone, or in conjunction with other cytokines (TNF- $\alpha$, IL-1, -2, -4, -8, $-10,-12,-18)$. IL-6 levels in plasma are rapidly dynamic and peaking at maximum from wound closure to POD1. IL-6 generally declined on POD1, and was back to baseline on POD3 [29, 39, 40, 42, 43, 45, 49, 52-54, 61, 62, $75,79,90]$. Patients with infection showed higher serum IL-6 than those without complication after surgical injury. However, the role of IL- 6 as a marker to diagnose sepsis or predict outcomes remains uncertain, and a wide range of cutoff values had been used (from 12 to $2760 \mathrm{pg} / \mathrm{ml}$ ). Fifteen studies reported that IL-6 appeared to be an indicator for sepsis or for predicting outcome/ mortality $[27,36,46-48,50,60,62,64,70,81,82,87$, $89,91]$. Conversely however, nine studies suggested IL-6 was a poor marker of disease severity $[28,35,55,65,66$, $72,80,83,96]$. The role of other cytokines as markers, such as IL-1 $\beta,-2,-4,-8,-10,-12,-18$, and TNF- $\alpha$ also remains elusive.

\section{DAMPs}

Recent studies have reported that DAMPs can act as proinflammatory mediators. Cohen et al. demonstrated high mobility group box protein 1 (HMGB1) was elevated in plasma early after injury and shock. Levels of HMGB1 correlated with injury severity and morbidity in trauma patients [3]. Similar results had been reported by Manganelli et al. in surgical patients [84]. HMGB1 level of the patients with peritonitis was higher than healthy controls [85, 99]. Mitochondrial DNA (mtDNA) has been proposed to be an inflammatory mediator, which was elevated early after trauma [105].

\section{Intraperitoneal mediators}

All studies that examined both systemic (blood) and peritoneal levels of mediators demonstrated that peritoneal mediator levels were 10-1000 times higher than systemic values in patients with peritonitis $[33,38,51$, $54,61,65,67,69,71,76,89,102]$. This suggests that measurement of peritoneal cytokines may be another and potentially more important method to determine and follow the patient's inflammatory reaction.

\section{Mechanistic studies}

Table S4 in Additional file 4 summarizes the eight clinical mechanistic studies that have been performed [107-114]. Moore et al. reported endotoxin could not be detected in portal or systemic blood in the first 48 hours post injury, and no differences were reported in terms of portal and systemic blood levels of IL- 6 and TNF- $\alpha$ between patients who developed MOF or not [107]. However, Adembri et al. carried out a small case-control study, and indicated a significant increase in blood IL-6 after reperfusion in aortic abdominal aneurysm surgery patients, which was followed by a significant reduction of lung function [111]. Sperry et al. reported blood IL-6 levels were statistically higher in males than females after injury [113]. In patients with severe peritonitis, the percentage of peritoneal neutrophils that engulfed Escherichia coli bacteria was significantly depressed when compared to patients without septic shock [108]. Moreover, severe peritonitis provoked an early pulmonary expression of chemoattractants, which enhanced neutrophil sequestration and activation in the lung [114].

\section{Intervention studies}

Table S5 in Additional file 5 lists the nine clinical intervention studies [115-123]. Four of which were randomized controlled trials (RCT). Three of the RCTs were from a single hospital comparing open surgery versus laparoscopy for treating perforated appendicitis, perforated peptic ulcer, or cholecystitis with sepsis [120-122]. Bakker et al. compared surgical to endoscopic necrosectomy for the treatment of infected necrotizing pancreatitis [119]. From these studies, the authors concluded that open surgery after peritonitis increased the incidence of bacteremia, endotoxemia, and systemic inflammation compared with laparoscopy. However, despite the direct linkage between endotoxin and inflammation, the use of polymyxin B-immobilized fiber to remove endotoxin or 
inflammatory mediators by direct hemoperfusion has proven to be of limited clinical value [116].

Kirkpatrick et al. performed a RCT looking at mediator levels in 45 patients with intra-abdominal sepsis or injury who needed open abdomen management, to determine whether active negative pressure peritoneal therapy with the ABThera device reduces systemic or peritoneal inflammation [123]. In this study, a significant 90-day mortality difference $(P=0.04)$ was observed among patients randomized to the ABThera (21.7\%) versus Barker's vacuum pack (50\%). Interestingly, there was no significant difference in clearance of the peritoneal or plasma IL-6 (or a number of other cytokines) between 24 and 48 hours among patients randomized to the ABThera versus Barker's vacuum pack.

\section{Animal studies}

Table S6 in Additional file 6 summarizes the mechanistic studies of mediators in animal models [124-170]. Thirty-nine of the 47 studies used rodents to develop abdominal sepsis models (i.e., cecum ligation and puncture (CLP)) [124, 125, 127, 128, 131-133, 136-138, 143, $145,151,154,156,157,159,162,164,165,167-170]$, or shock-resuscitation, or abdominal compartment syndrome (ACS), or two-hit models [126, 130, 132, 135$140,142,144,146-150,152,160-162,166]$. The remaining utilized swine $[129,134,155,158,163]$, baboons [141], or dogs [153]. These studies sought to address a wide range of mechanisms using various study designs. Four studies reported that balance of inflammatory mediators was closely related to severity and outcome of sepsis, and in these models IL-10 played a critical role to attenuate local and systemic mediators in animals with abdominal sepsis or injury [125-127, 140]. Ten reports used two-hit models, including shock (or ischemia) plus CLP or ACS [132, 134, 136, 137, 139, 155, $158,163]$. Overall these studies indicated that trauma or shock (the first hit) initiated an early proinflammatory response, resulting in priming and activation of neutrophils in peritoneum or other organs (lung, liver, kidney). The second insult (infection or ACS) further exaggerated this response, leading to MOF and mortality.

Studies also demonstrated that local (peritoneal) inflammatory mediator levels were not accurately reflected by systemic (blood) mediator levels. Generally, peritoneal mediator levels were much higher than the systemic levels, and thus might be a truer or better indicator of the local inflammatory response and outcomes [131, $154,158,163]$. The release of local mediators into the systemic circulation may help precipitate the deleterious effects of SIRS and sepsis. The lymphatic pathway appears to be a limiting step to systemic inflammatory response and subsequent lung injury following visceral ischemia and reperfusion [141, 153, 160].
Knockout animal studies demonstrated IL-10 was a potent anti-inflammatory mediator, resulting in the attenuation of lung neutrophil infiltration and injury after visceral ischemia [140]. ICAM-1-deficient mice undergoing CLP peritonitis showed better survival with less tissue damage and lower levels of plasma cytokines than their wild-type littermates [143]. Deficiency for the chemoattractant MIP- $1 \alpha$ attenuated Kupffer cell cytokine production and systemic mediators following hemorrhage shock and resuscitation [148].

Table S7 in Additional file 7 lists the preclinical intervention studies performed on intra-abdominal sepsis models [171-202]. Use of anti-TNF antibody in mice subjected to CLP sepsis significantly reduced TNF- $\alpha$ bioactivity but interestingly did not reduce mortality $[171,172]$. Administration of androgen receptor blocker and estrogen receptor agonists (flutamide, dehydroepiandrosterone) ameliorated a male genderrelated immunity imbalance after hemorrhagic shock, reduced cytokine production resulting in improved animal survival during a subsequent septic challenge $[144,147,173,174,179,185]$. Treatment with antiHMGB1 antibody in mice after shock-resuscitation improved survival and ameliorated gut barrier dysfunction with lower blood cytokines [186]. Intravenous administration of a $\omega-3$ fatty acid improved survival in mice CLP sepsis, and reduced blood cytokine levels [196]. Kubiak et al. reported that systemic and peritoneal inflammation was reduced with less organ damage in pigs with peritonitis treated by negative pressure therapy [190]. Although animal studies appear promising, one should keep in mind that many of these studies are small in nature. Furthermore, many limitations remain in translation of animal data to clinical application. In animal models, the insults are controlled; interventions can begin shortly after infection. In humans, the diagnosis is usually made much later. Thus it is essential that more evidence for the use of these interventions is gathered using clinical feasible models and larger sample size studies.

\section{Discussion}

This scoping review focused on examining the reported role of inflammatory and protein mediators in intraabdominal sepsis or injuries. In surgical ICU patients, traumatic injuries and septic conditions can be simultaneously or subsequently present. Each can be associated with profound and dynamic production of bioactive mediators that are at the present poorly understood, particularly in terms of their kinetics and overall interaction with the host inflammatory response. This inflammatory response is a complex and multifaceted process. Traumatic injuries induce overwhelming reactions in the immunological and neurohormonal systems. Innate immunocytes are activated by hypoxia stress and endogenous signals 
(DAMPs) released by damaged tissues $[4,6,203]$. These reactions are thought to represent attempts to adjust physiology for maintenance of homeostasis. These responses however often result in positive feedback loops leading to excessive cytokine production and uncontrolled inflammation. In the early phase following injury, the response is regulated by acute phase reactants, proinflammatory mediators (TNF- $\alpha, \mathrm{IL}-1,-6,-8,-18)$, and the activation of endothelial cells (expression of $\mathrm{P}$ and E-selectins, ICAM-1, VCAM-1), leading to a socalled "sterile" systemic inflammatory response or SIRS. At the same time, anti-inflammatory mediators (IL-10) are released in an attempt to balance the proinflammatory reaction. Polytrauma patients with excessive SIRS can not only progress to multiple organ damage and failure (MOF), but also develop persistent inflammation, immunosuppression, and catabolism syndrome (PICS), which lead to infectious sepsis resulting in release of additional DAMPs and PAMPs, perpetuating a vicious cycle of inflammation $[4,203]$. Therefore, during this late phase post injury, trauma patients are prone to develop infective complications with high mortality rate. Injuries to the abdomen and visceral organs are common clinical scenarios, and are usually complicated with intraabdominal sepsis [123]. The objective of this scoping review was to search for current evidence of mediators as biomarkers and their roles in intra-abdominal sepsis or injury.

Although animal studies suggest that mediators play a critical role in both the pathogenesis and potential management in intra-abdominal sepsis/injury, the clinical evidence to support measuring mediators as biomarkers to discriminate SIRS from sepsis is conflicting.

Due to the heterogeneity of included studies, we discussed the overall results based on the "best-evidence synthesis" rating, which is widely used in narrative and systematic reviews [18]. Moderate evidence supports utilizing serum CRP as a biomarker for diagnosing acute appendicitis with sepsis $[25,26,32,47,70]$; or as a potential indicator for predicting complications (abscess, anastomotic leaks) after major abdominal surgery [21, 92, 98, 103]. A normal CRP response to therapy, or absence of secondary rise after surgery, may help to exclude infection [24]. It is important to note that no standard cutoff value was available, and some studies have reported negative results for using CRP as a biomarker [64, 86, 96].

Furthermore, although the serum PCT value appears to predict severity of septic complications $[49,64]$, it does not appear to be an ideal biomarker to discriminate SIRS from sepsis. Persistently high PCT levels appear to be associated with a significant increase in mortality in patients with sepsis $[77,88,93,95]$. The role of using serum PCT as a guide to monitor patients' response to therapy remains to be determined [74, 78].

Sepsis further increased IL-6 levels over the already elevated levels from the original injury. Although moderate level of evidence supports IL-6 to be a useful indicator for sepsis or severity $[48,64,87,91]$, it is important to note that almost half of the studies for this cytokine do not support the use of IL-6 as a good sepsis biomarker. Currently, no evidence is available to support the use of TNF- $\alpha$ or other cytokines in diagnosing sepsis or predicting outcomes. Recent studies have reported endogenous DAMPs (mtDNA, HMGB1) released as a consequence of tissue injury or infection appear to be promising biomarkers $[3,84,85,99,105]$; however, the evidence supporting their role is still limited.

It appeared to be futile to specifically target a single inflammatory or protein mediator in an effort to mitigate disease and improve outcomes. It is more likely that identifying promising biomarkers will only be possible when a number of mediators are analyzed as a profile [204, 205].

It is currently unknown if the peritoneal cavity functions to restrain the inflammatory mediators or to act as a reservoir of mediators. Evidence has shown that peritoneal fluid functions as a priming and activating stimulus for neutrophils both in the peritoneum and in remote organs (lung, liver, kidneys) after injury, enhancing the incidence of MOF upon subsequent infection $[136,163]$. Moreover, early removal of peritoneal fluid appeared to reduce systemic inflammation and organ dysfunction [123, 141, 153, 160, 190]. This notion supports the recent guidelines for management of intra-abdominal infections proposed by the World Society of Emergency Surgery [206].

Finally, based on the evidence from animal models that injury followed by a second insult (infection, or ACS) substantially enhanced the inflammatory response and organ damage [134, 136, 158, 163, 190], it is essential to avoid or timely intervene upon secondary insults for trauma patients to improve outcomes.

This review has limitations. First, despite the search of multiple databases using comprehensive search strategies with the assistance of a medical librarian, our search has excluded studies assessing extra-abdominal sepsis or injury. Moreover, limited abdominal trauma studies were available; the majority of which focused on surgical injuries. Importantly, the exclusion of studies assessing other kinds of sepsis can present a selection bias. Second, due to the inconsistencies in study design, it proved difficult to extract accurate data from all studies, even with the assistance of predefined data abstraction tools. Furthermore, only a small number of the included studies actually examined biomarkers for both sensitivity and specificity. 


\section{Conclusions}

Systemic inflammatory response syndrome is the expected immunologic response to both infection and traumatic injuries, which makes the distinction between infectious sepsis and sterile SIRS exceedingly difficult. Although animal studies suggest that mediators play an important role, the clinical use of mediators as biomarkers in discriminating SIRS from sepsis in intra-abdominal injury or sepsis is conflicting. Persistent elevation of CRP or PCT levels in blood appears to be correlated with septic complications. The role of IL- 6 as a biomarker in intra-abdominal sepsis is controversial. Limited evidence suggests endogenous molecules may be candidate biomarkers of sepsis or injury. Importantly, peritoneal mediator levels cannot be proportionately reflected by the systemic levels. Victims subjected to trauma followed by infection show more excessive inflammatory response and organ damage than those to trauma only. To date, therapies targeting a specific inflammatory or protein mediator in abdominal sepsis have shown poor results. Interventions aiming to remove peritoneal fluid/mediators and improve outcomes are still investigational. Large sample size randomized controlled trails are desirable to identify the "ideal" biomarker(s) and understand the roles of mediators in intra-abdominal sepsis and injury.

\section{Key messages}

- Preclinical studies demonstrate that intra-abdominal injury/ischemia, especially with subsequent infection, induces an excessive inflammatory/protein mediator production and uncontrolled inflammation in the peritoneum and remote organs.

- Both preclinical and clinical studies have shown the peritoneal mediator levels are much higher than the blood levels, and the release of these mediators (mostly via the lymphatic pathway) into the systemic circulation may precipitate the deleterious effects of sepsis and multiple organ dysfunction.

- Normal postoperative clearance kinetics of CRP, PCT, or IL-6 may help rule out infection or complications.

- The clinical role of measuring inflammatory/protein mediators as biomarkers to diagnose abdominal infection or predict outcomes of abdominal sepsis or injury remains to be established. High-quality clinical trials are warranted to determine the role of mediators in intra-abdominal sepsis and injury.

\section{Additional files}

Additional file 1: Table S1. Search strategies. (DOCX $17 \mathrm{~kb}$ )

Additional file 2: Table S2. Best-evidence synthesis. (DOCX $15 \mathrm{~kb}$ )
Additional file 3: Table S3. Clinical biomarkers. (DOCX $76 \mathrm{~kb}$ )

Additional file 4: Table S4. Clinical mechanism. (DOCX $19 \mathrm{~kb})$

Additional file 5: Table S5. Clinical intervention. (DOCX $22 \mathrm{~kb}$ )

Additional file 6: Table S6. Preclinical mechanism. (DOCX $46 \mathrm{~kb}$ )

Additional file 7: Table S7. Preclinical intervention. (DOCX $36 \mathrm{~kb}$ )

\section{Abbreviations}

ACS: abdominal compartment syndrome; CLP: cecum ligation and puncture; CRP: C-reactive protein; DAMPs: damage-associated molecular patterns; HMGB1: high mobility group box protein 1; ICU: intensive care unit; IL: interleukin; mtDNA: mitochondrial DNA; MOF: multiple organ failure; PAMPs: pathogen-associated molecular patterns; PCT: procalcitonin; PICS: persistent inflammation, immunosuppression, and catabolism syndrome; POD: postoperative day; PRRs: pattern recognition receptors; RCT: randomized controlled trial; SIRS: systemic inflammatory response syndrome; TLRs: Toll-like receptors; TNF: tumor necrosis factor.

\section{Competing interests}

Professor Kirkpatrick received a research grant from Kinetic Concepts Inc., USA and afterwards consulted for Acelity Corp. AWK has received travel reimbursement to attend cadaver and research laboratories from the Life Cell and Innovative Trauma Care Corporations. The remaining authors have none to declare.

\section{Authors' contributions}

ZX conceptualized the study, created the study design, conducted the literature search, collected data, drafted and revised the manuscript. CW participated in the study design, collected data, drafted and revised the manuscript. HLR participated in the study design, conducted the literature search and revised the manuscript critically for important intellectual content. DJR participated in the study design, performed data analysis, and critically revised the manuscript for important intellectual content. CGB participated in the study design, drafted and critically revised the manuscript for important intellectual content. CNJ participated in the study design, drafted and critically revised the manuscript for important intellectual content. AWK conceptualized the study, created the study design, drafted and critically revised the manuscript for important intellectual content. All authors read and approved the final manuscript.

\section{Author details}

${ }^{1}$ Regional Trauma Services, Foothills Medical Centre, $1403-29$ Street NW, T2N 2T9 Calgary, AB, Canada. ${ }^{2}$ Health Sciences Library, Health Sciences Centre, University of Calgary, 3330 Hospital Drive NW, T2N 4N1 Calgary, AB, Canada. ${ }^{3}$ Department of Surgery, Foothills Medical Centre, University of Calgary, 1403 - 29 Street NW, T2N 2T9 Calgary, AB, Canada. ${ }^{4}$ Department of Community Health Sciences (Division of Epidemiology), University of Calgary, 3280 Hospital Drive Northwest, T2N 4 Z6 Calgary, AB, Canada. ${ }^{5}$ Department of Critical Care Medicine, Foothills Medical Centre, University of Calgary, 3134 Hospital Drive NW, T2N 5A1 Calgary, AB, Canada. ${ }^{6}$ Department of Microbiology, Immunology and Infectious Diseases, University of Calgary, 3280 Hospital Drive NW, T2N 4N1 Calgary, AB, Canada.

Received: 4 June 2015 Accepted: 7 October 2015

Published online: 27 October 2015

\section{References}

1. Oberholzer A, Oberholzer C, Moldawer LL. Sepsis syndromes: understanding the role of innate and acquired immunity. Shock (Augusta, Ga). 2001;16:83-96.

2. Tsukamoto T, Chanthaphavong RS, Pape HC. Current theories on the pathophysiology of multiple organ failure after trauma. Injury. 2010;41:21-6.

3. Cohen MJ, Brohi K, Calfee CS, Rahn P, Chesebro BB, Christiaans SC, et al. Early release of high mobility group box nuclear protein 1 after severe trauma in humans: role of injury severity and tissue hypoperfusion. Crit Care. 2009;13:R174

4. Zhang Q, Raoof M, Chen Y, Sumi Y, Sursal T, Junger W, et al. Circulating mitochondrial DAMPs cause inflammatory responses to injury. Nature. 2010;464:104-7. 
5. Matzinger P. The danger model: a renewed sense of self. Science. 2002;296:301-5.

6. West AP, Shadel GS, Ghosh S. Mitochondria in innate immune responses. Nat Rev Immunol. 2011;11:389-402.

7. Hotchkiss RS, Opal S. Immunotherapy for sepsis-a new approach against an ancient foe. N Engl J Med. 2010;363:87-9.

8. Angus DC, Linde-Zwirble WT, Lidicker J, Clermont G, Carcillo J, Pinsky MR. Epidemiology of severe sepsis in the United States: analysis of incidence, outcome, and associated costs of care. Crit Care Med. 2001;29:1303-10.

9. Martin GS, Mannino DM, Eaton S, Moss M. The epidemiology of sepsis in the United States from 1979 through 2000. N Engl J Med. 2003;348:1546-54.

10. Levy MM, Fink MP, Marshall JC, Abraham E, Angus D, Cook D, et al. 2001 SCCM/ESICM/ACCP/ATS/SIS International Sepsis Definitions Conference. Crit Care Med. 2003;31:1250-6.

11. Wanner GA, Keel M, Steckholzer U, Beier W, Stocker R, Ertel W. Relationship between procalcitonin plasma levels and severity of injury, sepsis, organ failure, and mortality in injured patients. Crit Care Med. 2000;28:950-7.

12. Anderson R, Schmidt R. Clinical biomarkers in sepsis. Front Biosci (Elite Ed). 2010;2:504-20.

13. Levac D, Colquhoun H, O'Brien KK. Scoping studies: advancing the methodology. Implement Sci. 2010;5:69.

14. Berlin JA. Does blinding of readers affect the results of meta-analyses? University of Pennsylvania Meta-analysis Blinding Study Group. Lancet. 1997;350:185-6.

15. Knaus WA, Draper EA, Wagner DP, Zimmerman JE. APACHE II: a severity of disease classification system. Crit Care Med. 1985;13:818-29.

16. Vincent JL, Moreno R, Takala J, Willatts S, De Mendonca A, Bruining H, et al. The SOFA (Sepsis-related Organ Failure Assessment) score to describe organ dysfunction/failure. On behalf of the Working Group on Sepsis-Related Problems of the European Society of Intensive Care Medicine. Intensive Care Med. 1996;22:707-10.

17. Baker SP, O'Neill B, Haddon Jr W, Long WB. The injury severity score: a method for describing patients with multiple injuries and evaluating emergency care. J Trauma. 1974;14:187-96.

18. Ciriello V, Gudipati S, Stavrou PZ, Kanakaris NK, Bellamy MC, Giannoudis PV. Biomarkers predicting sepsis in polytrauma patients: current evidence. Injury. 2013:44:1680-92.

19. Furlan AD, Pennick V, Bombardier C, van Tulder M. 2009 updated method guidelines for systematic reviews in the Cochrane Back Review Group. Spine. 2009;34:1929-41.

20. Hayden JA, van der Windt DA, Cartwright $J$, Cote P, Bombardier C. Assessing bias in studies of prognostic factors. Ann Intern Med. 2013;158:280-6.

21. Schentag JJ, O'Keeffe D, Marmion M, Wels PB. C-reactive protein as an indicator of infection relapse in patients with abdominal sepsis. Arch Surg. 1984;119:300-4.

22. Duswald KH, Jochum M, Schramm W, Fritz H. Released granulocytic elastase: an indicator of pathobiochemical alterations in septicemia after abdominal surgery. Surgery. 1985;98:892-9

23. Deby-Dupont G, Braun M, Lamy M, Deby C, Pincemail J, Faymonville ME, et al. Thromboxane and prostacyclin release in adult respiratory distress syndrome. Intensive Care Med. 1987;13:167-74

24. Mustard Jr RA, Bohnen JM, Haseeb S, Kasina R. C-reactive protein levels predict postoperative septic complications. Arch Surg. 1987;122:69-73.

25. Ingram RR, Mohammed R, Tillman J. C-reactive protein and acute appendicitis. J R Coll Surg Edinb. 1988;33:115-6.

26. Dueholm S, Bagi P, Bud M. Laboratory aid in the diagnosis of acute appendicitis. A blinded, prospective trial concerning diagnostic value of leukocyte count, neutrophil differential count, and C-reactive protein. Dis Colon Rectum. 1989:32:855-9

27. Damas $P$, Ledoux $D$, Nys $M$, Vrindts $Y$, De Groote $D$, Franchimont $P$, et al. Cytokine serum level during severe sepsis in human IL-6 as a marker of severity. Ann Surg. 1992;215:356-62.

28. Hamilton G, Hofbauer S, Hamilton B. Endotoxin, TNF-alpha, interleukin-6 and parameters of the cellular immune system in patients with intraabdominal sepsis. Scand J Infect Dis. 1992;24:361-8.

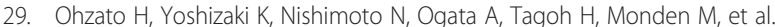
Interleukin- 6 as a new indicator of inflammatory status: detection of serum levels of interleukin-6 and C-reactive protein after surgery. Surgery. 1992;111:201-9.

30. Fugger R, Zadrobilek E, Gotzinger P, Klimann S, Rogy M, Winkler S, et al. Perioperative TNF alpha and IL-6 concentrations correlate with septic state, organ function, and APACHE II scores in intra-abdominal infection. Eur J Surg. 1993;159:525-9.

31. Cabie A, Farkas JC, Fitting C, Laurian C, Cormier JM, Carlet J, et al. High levels of portal TNF-alpha during abdominal aortic surgery in man. Cytokine. 1993;5:448-53.

32. Gurleyik E, Gurleyik G, Unalmiser S. Accuracy of serum C-reactive protein measurements in diagnosis of acute appendicitis compared with surgeon's clinical impression. Dis Colon Rectum. 1995;38:1270-4.

33. Holzheimer RG, Schein M, Wittmann DH. Inflammatory response in peritoneal exudate and plasma of patients undergoing planned relaparotomy for severe secondary peritonitis. Arch Surg. 1995;130:1314-9. discussion 1319-20.

34. Kaufmann P, Tilz GP, Smolle KH, Demel U, Krejs GJ. Increased plasma concentrations of circulating intercellular adhesion molecule-1 (cICAM-1) in patients with necrotizing pancreatitis. Immunobiology. 1996;195:209-19.

35. Riche F, Panis Y, Laisne MJ, Briard C, Cholley B, Bernard-Poenaru O, et al. High tumor necrosis factor serum level is associated with increased survival in patients with abdominal septic shock: a prospective study in 59 patients. Surgery. 1996;120:801-7.

36. Tang GJ, Kuo CD, Yen TC, Kuo HS, Chan KH, Yien HW, et al. Perioperative plasma concentrations of tumor necrosis factor-alpha and interleukin-6 in infected patients. Crit Care Med. 1996;24:423-8.

37. Hammond JM, Potgieter PD. The influence of surgery on cytokines in patients with intra-abdominal sepsis. Anaesth Intensive Care. 1996;24:430-4.

38. Frohlich D, Eiber RM, Jochum M, Billing A. Perioperative pattern of peritoneal interleukin 8, tumour necrosis factor-alpha, and granulocyte elastase release in human secondary peritonitis. Cytokine. 1997;9:288-92.

39. Berger D, Bolke E, Seidelmann M, Beger HG. Time-scale of interleukin-6, myeloid related proteins (MRP), C reactive protein (CRP), and endotoxin plasma levels during the postoperative acute phase reaction. Shock. 1997:7:422-6.

40. Gilliland HE, Armstrong MA, Carabine U, McMurray TJ. The choice of anesthetic maintenance technique influences the antiinflammatory cytokine response to abdominal surgery. Anesth Analg. 1997;85:1394-8.

41. Groeneveld AB, Raijmakers PG, Rauwerda JA, Hack CE. The inflammatory response to vascular surgery-associated ischaemia and reperfusion in man: effect on postoperative pulmonary function. Eur J Vasc Endovasc Surg. 1997;14:351-9.

42. Donati A, Battisti D, Recchioni A, Paoletti P, Conti G, Caporelli S, et al. Predictive value of interleukin 6 (IL-6), interleukin 8 (IL-8) and gastric intramucosal $\mathrm{pH}(\mathrm{pH}-\mathrm{i})$ in major abdominal surgery. Intensive Care Med. 1998;24:329-35

43. Kato M, Honda I, Suzuki H, Murakami M, Matsukawa S, Hashimoto Y. Interleukin-10 production during and after upper abdominal surgery. J Clin Anesth. 1998;10:184-8.

44. Simovic MO, Bonham MJD, Abu-Zidan FM, Windsor JA. Anti-inflammatory cytokine response and clinical outcome in acute pancreatitis. Crit Care Med. 1999;27:2662-5.

45. Holmberg A, Bergqvist D, Westman B, Siegbahn A. Cytokine and fibrinogen response in patients undergoing open abdominal aortic aneurysm surgery. Eur J Vasc Endovasc Surg. 1999;17:294-300.

46. Pape HC, Remmers D, Grotz M, Schedel I, von Glinski S, Oberbeck R, et al. Levels of antibodies to endotoxin and cytokine release in patients with severe trauma: does posttraumatic dysergy contribute to organ failure? J Trauma. 1999:46:907-13.

47. Erkasap S, Ates E, Ustuner Z, Sahin A, Yilmaz S, Yasar B, et al. Diagnostic value of interleukin- 6 and $C$-reactive protein in acute appendicitis. Swiss Surg. 2000;6:169-72.

48. Holzheimer RG, Capel P, Cavaillon JM, Cainzos M, Frileux P, Haupt W, et al. Immunological surrogate parameters in a prognostic model for multi-organ failure and death. Eur J Med Res. 2000:5:283-94.

49. Reith HB, Mittelkotter U, Wagner R, Thiede A. Procalcitonin (PCT) in patients with abdominal sepsis. Intensive Care Med. 2000;26:S165-169.

50. Riche FC, Cholley BP, Panis YH, Laisne MJ, Briard CG, Graulet AM, et al. Inflammatory cytokine response in patients with septic shock secondary to generalized peritonitis. Crit Care Med. 2000;28:433-7.

51. Scheingraber S, Bauerfeind F, Bohme J, Dralle H. Limits of peritoneal cytokine measurements during abdominal lavage treatment for intraabdominal sepsis. Am J Surg. 2001;181:301-8.

52. Bolke E, Jehle PM, Graf M, Baier A, Wiedeck H, Steinbach G, et al. Inflammatory response during abdominal and thyroid surgery: a prospective clinical trial on mediator release. Shock. 2001;16:334-9. 
53. Buttenschoen K, Buttenschoen DC, Berger D, Vasilescu C, Schafheutle S, Goeltenboth B, et al. Endotoxemia and acute-phase proteins in major abdominal surgery. Am J Surg. 2001;181:36-43

54. Wiik H, Karttunen R, Haukipuro K, Syrjala H. Maximal local and minimal systemic cytokine response to colorectal surgery: the influence of perioperative filgrastim. Cytokine. 2001;14:188-92.

55. Gurleyik G, Gurleyik E, Cetinkaya F, Unalmiser S. Serum interleukin-6 measurement in the diagnosis of acute appendicitis. ANZ J Surg. 2002;72:665-7.

56. Herwig R, Glodny B, Kuhle C, Schluter B, Brinkmann OA, Strasser H, et al. Early identification of peritonitis by peritoneal cytokine measurement. Dis Colon Rectum. 2002;45:514-21.

57. Lindberg M, Hole A, Johnsen H, Asberg A, Rydning A, Myrvold HE, et al. Reference intervals for procalcitonin and C-reactive protein after major abdominal surgery. Scand J Clin Lab Invest. 2002;62:189-94.

58. Ikuta S, Ono S, Kinoshita M, Tsujimoto H, Yamauchi A, Mochizuki H. Interleukin-18 concentration in the peritoneal fluid correlates with the severity of peritonitis. Am J Surg. 2003;185:550-5.

59. Yang MD, Jeng LB, Kao A, Lin CC, Lee CC. C-reactive protein and gallium scintigraphy in patients after abdominal surgery. Hepatogastroenterology. 2003;50:354-6

60. Latifi SQ, O'Riordan MA, Levine AD, Stallion A. Persistent elevation of serum interleukin-6 in intraabdominal sepsis identifies those with prolonged length of stay. J Pediatr Surg. 2004;39:1548-52.

61. Jansson K, Redler B, Truedsson L, Magnuson A, Matthiessen P, Andersson M, et al. Intraperitoneal cytokine response after major surgery: higher postoperative intraperitoneal versus systemic cytokine levels suggest the gastrointestinal tract as the major source of the postoperative inflammatory reaction. Am J Surg. 2004;187:372-7.

62. Chachkhiani I, Gurlich R, Maruna P, Frasko R, Lindner J. The postoperative stress response and its reflection in cytokine network and leptin plasma levels. Physiol Res. 2005;54:279-85.

63. Karamarkovic A, Radenkovic D, Milic N, Bumbasirevic V, Stefanovic B. Protein $C$ as an early marker of severe septic complications in diffuse secondary peritonitis. World J Surg. 2005;29:759-65

64. Mokart D, Merlin M, Sannini A, Brun JP, Delpero JR, Houvenaeghel G, et al. Procalcitonin, interleukin 6 and systemic inflammatory response syndrome (SIRS): early markers of postoperative sepsis after major surgery. $\mathrm{Br} J$ Anaesth. 2005;94:767-73.

65. Yamamoto T, Umegae S, Kitagawa T, Matsumoto K. Intraperitoneal cytokine productions and their relationship to peritoneal sepsis and systemic inflammatory markers in patients with inflammatory bowel disease. Dis Colon Rectum. 2005:48:1005-15.

66. Sarbinowski R, Arvidsson S, Tylman M, Oresland T, Bengtsson A. Plasma concentration of procalcitonin and systemic inflammatory response syndrome after colorectal surgery. Acta Anaesthesiol Scand. 2005;49:191-6.

67. Kermarrec N, Selloum S, Plantefeve G, Chosidow D, Paoletti X, Lopez A, et al. Regulation of peritoneal and systemic neutrophil-derived tumor necrosis factor-alpha release in patients with severe peritonitis: role of tumor necrosis factor-alpha converting enzyme cleavage. Crit Care Med. 2005;33:1359-64

68. Birchley D. Patients with clinical acute appendicitis should have pre-operative full blood count and C-reactive protein assays. Ann R Coll Surg Engl. 2006:88:27-32.

69. Haecker FM, Fasler-Kan E, Manasse C, Fowler B, Hertel R, von Schweinitz D. Peritonitis in childhood: clinical relevance of cytokines in the peritoneal exudate. Eur J Pediatr Surg. 2006;16:94-9.

70. Sack U, Biereder B, Elouahidi T, Bauer K, Keller T, Trobs RB. Diagnostic value of blood inflammatory markers for detection of acute appendicitis in children. BMC Surg. 2006;6:15

71. Kowal-Vern A, Ortegel J, Bourdon P, Chakrin A, Latenser BA, Kimball D, et al. Elevated cytokine levels in peritoneal fluid from burned patients with intra-abdominal hypertension and abdominal compartment syndrome. Burns. 2006;32:563-9.

72. Dimopoulou I, Armaganidis A, Douka E, Mavrou I, Augustatou C, Kopterides $P$, et al. Tumour necrosis factor-alpha (TNFalpha) and interleukin-10 are crucial mediators in post-operative systemic inflammatory response and determine the occurrence of complications after major abdominal surgery. Cytokine. 2007;37:55-61.

73. Novotny AR, Emmanuel K, Maier S, Westerholt A, Weighardt H, Stadler J, et al. Cytochrome P450 activity mirrors nitric oxide levels in postoperative sepsis: predictive indicators of lethal outcome. Surgery. 2007;141:376-84.
74. Svoboda P, Kantorova I, Scheer P, Radvanova J, Radvan M. Can procalcitonin help us in timing of re-intervention in septic patients after multiple trauma or major surgery? Hepatogastroenterology. 2007;54:359-63.

75. Ilias I, Tzanela M, Mavrou I, Douka E, Kopterides P, Armaganidis A, et al. Thyroid function changes and cytokine alterations following major surgery. Neuroimmunomodulation. 2007;14:243-7.

76. Determann RM, van Till JWO, van Ruler O, van Veen SQ, Schultz MJ, Boermeester MA. sTREM-1 is a potential useful biomarker for exclusion of ongoing infection in patients with secondary peritonitis. Cytokine. 2009:46:36-42.

77. Novotny AR, Emmanuel K, Hueser N, Knebel C, Kriner M, Ulm K, et al. Procalcitonin ratio indicates successful surgical treatment of abdominal sepsis. Surgery. 2009;145:20-6.

78. Schroeder S, Hochreiter M, Koehler T, Schweiger AM, Bein B, Keck FS, et al. Procalcitonin (PCT)-guided algorithm reduces length of antibiotic treatment in surgical intensive care patients with severe sepsis: results of a prospective randomized study. Langenbecks Arch Surg. 2009;394:221-6.

79. Buttenschoen K, Schneider ME, Utz K, Kornmann M, Beger HG, Carli BD. Effect of major abdominal surgery on endotoxin release and expression of Toll-like receptors 2/4. Langenbecks Arch Surg. 2009;394:293-302.

80. Hofer S, Brenner T, Bopp C, Steppan J, Lichtenstern C, Weitz J, et al. Cell death serum biomarkers are early predictors for survival in severe septic patients with hepatic dysfunction. Crit Care. 2009;13:R93.

81. Bingold TM, Ziesche E, Scheller B, Sadik CD, Franck K, Just $L$, et al. Interleukin-22 detected in patients with abdominal sepsis. Shock. 2010;34:337-40.

82. Brenner T, Hofer S, Rosenhagen C, Steppan J, Lichtenstern C, Weitz J, et al, Macrophage migration inhibitory factor (MIF) and manganese superoxide dismutase (MnSOD) as early predictors for survival in patients with severe sepsis or septic shock. J Surg Res. 2010;164:e163-171.

83. Hranjec T, Swenson BR, Dossett LA, Metzger R, Flohr TR, Popovsky KA, et al. Diagnosis-dependent relationships between cytokine levels and survival in patients admitted for surgical critical care. J Am Coll Surg. 2010;210:833-44.

84. Manganelli V, Signore M, Pacini I, Misasi R, Tellan G, Garofalo T, et al. Increased HMGB1 expression and release by mononuclear cells following surgical/anesthesia trauma. Crit Care. 2010;14:R197.

85. Albayrak Y, Albayrak A, Celik M, Gelincik I, Demiryilmaz I, Yildirim R, et al. High mobility group box protein-1 (HMGB-1) as a new diagnostic marker in patients with acute appendicitis. Scand J Trauma Resusc Emerg Med. 2011;19:27.

86. Kumar RV, Kumar RM, Pradeep Kumar NS, Ananthakrishnan N. Diagnostic value of C-reactive protein in suspected acute appendicitis-a prospective case control study. Indian J Med Sci. 2011;65:399-405.

87. Ravishankaran P, Shah AM, Bhat R. Correlation of interleukin-6, serum lactate, and C-reactive protein to inflammation, complication, and outcome during the surgical course of patients with acute abdomen. J Interferon Cytokine Res. 2011;31:685-90.

88. Tschaikowsky K, Hedwig-Geissing M, Braun GG, Radespiel-Troeger M. Predictive value of procalcitonin, interleukin-6, and C-reactive protein for survival in postoperative patients with severe sepsis. J Crit Care. 2011;26:54-64.

89. Yamamoto T, Umegae S, Matsumoto K, Saniabadi AR. Peritoneal cytokines as early markers of peritonitis following surgery for colorectal carcinoma: a prospective study. Cytokine. 2011;53:239-42.

90. Nguyen-Vermillion A, Juul SE, McPherson RJ, Ledbetter DJ. Time course of C-reactive protein and inflammatory mediators after neonatal surgery. J Pediatr. 2011;159:121-6.

91. Steppan J, Hofer S, Funke B, Brenner T, Henrich M, Martin E, et al. Sepsis and major abdominal surgery lead to flaking of the endothelial glycocalix. J Surg Res. 2011;165:136-41.

92. Almeida AB, Faria G, Moreira H, Pinto-de-Sousa J, Correia-da-Silva P, Maia JC. Elevated serum C-reactive protein as a predictive factor for anastomotic leakage in colorectal surgery. Int J Surg. 2012;10:87-91.

93. Azevedo JR, Torres OJ, Czeczko NG, Tuon FF, Nassif PA, Souza GD. Procalcitonin as a prognostic biomarker of severe sepsis and septic shock. Rev Col Bras Cir. 2012:39:456-61.

94. Benkoe T, Reck C, Gleiss A, Kettner S, Repa A, Horcher E, et al. Interleukin 8 correlates with intestinal involvement in surgically treated infants with necrotizing enterocolitis. J Pediatr Surg. 2012;47:1548-54.

95. Bezmarevic M, Mirkovic D, Soldatovic I, Stamenkovic D, Mitrovic N, Perisic N, et al. Correlation between procalcitonin and intra-abdominal pressure and 
their role in prediction of the severity of acute pancreatitis. Pancreatology. 2012;12:337-43.

96. Celik IH, Yilmaz Y, Erdeve O, Demirel G, Oguz SS, Uras N, et al. The acute-phase response in differentiating sepsis from inflammation in neonates who require abdominal surgery. Acta Chir Belg. 2012;112:292-6.

97. Kimura A, Ono S, Hiraki S, Takahata R, Tsujimoto H, Miyazaki H, et al. The postoperative serum interleukin-15 concentration correlates with organ dysfunction and the prognosis of septic patients following emergency gastrointestinal surgery. J Surg Res. 2012;175:e83-88.

98. Witczak A, Juralowicz P, Modzelewski B, Gawlik M. C-reactive protein as a marker of postoperative septic complications. Pol Przegl Chir. 2012;84:93-8.

99. Wu C, Sun H, Wang H, Chi J, Liu Q, Guo H, et al. Evaluation of high mobility group box 1 protein as a presurgical diagnostic marker reflecting the severity of acute appendicitis. Scand J Trauma Resusc Emerg Med. 2012;20:61.

100. Barbic J, Ivic D, Alkhamis T, Drenjancevic D, Ivic J, Harsanji-Drenjancevic I, et al. Kinetics of changes in serum concentrations of procalcitonin, interleukin-6, and C- reactive protein after elective abdominal surgery. Can it be used to detect postoperative complications? Coll Antropol. 2013;37:195-201.

101. Jung B, Molinari N, Nasri M, Hajjej Z, Chanques G, Jean-Pierre $H$, et al. Procalcitonin biomarker kinetics fails to predict treatment response in perioperative abdominal infection with septic shock. Crit Care. 2013;17:R255.

102. Riche F, Gayat E, Collet C, Mateo J, Laisne MJ, Launay JM, et al. Local and systemic innate immune response to secondary human peritonitis. Crit Care. 2013;17:R201.

103. Scepanovic MS, Kovacevic B, Cijan V, Antic A, Petrovic Z, Asceric R, et al. C-reactive protein as an early predictor for anastomotic leakage in elective abdominal surgery. Tech Coloproctol. 2013;17:541-7.

104. Stamataki E, Stathopoulos A, Garini E, Kokkoris S, Glynos C, Psachoulia C, et al. Serum S100B protein is increased and correlates with interleukin 6 , hypoperfusion indices, and outcome in patients admitted for surgical control of hemorrhage. Shock. 2013;40:274-80.

105. Yamanouchi S, Kudo D, Yamada M, Miyagawa N, Furukawa H, Kushimoto S. Plasma mitochondrial DNA levels in patients with trauma and severe sepsis: time course and the association with clinical status. J Crit Care. 2013;28:1027-31

106. Zhu $P$, Liang Z, Fu J, Chen W, Wang Z, Jiang $H$, et al. Procalcitonin in abdominal exudate to predict prolonged postoperative ileus following colorectal carcinoma surgery. Int J Biol Markers. 2013;28:187-91.

107. Moore FA, Moore EE, Poggetti R, McAnena OJ, Peterson VM, Abernathy CM, et al. Gut bacterial translocation via the portal vein: a clinical perspective with major torso trauma. J Trauma. 1991;31:629-36. discussion 636-8.

108. Holzer K, Konietzny P, Wilhelm K, Encke A, Henrich D. Phagocytosis by emigrated, intra-abdominal neutrophils is depressed during human secondary peritonitis. Eur Surg Res. 2002;34:275-84

109. Poeze M, Ramsay G, Buurman WA, Greve JWM, Dentener M, Takala J. Increased hepatosplanchnic inflammation precedes the development of organ dysfunction after elective high-risk surgery. Shock. 2002;17:451-8.

110. Riese J, Schoolmann S, Denzel C, Herrmann O, Hohenberger W, Haupt W. Effect of abdominal infections on peritoneal and systemic production of interleukin 6 and monocyte chemoattractant protein-1. Shock. 2002;17:361-4.

111. Adembri C, Kastamoniti E, Bertolozzi I, Vanni S, Dorigo W, Coppo M, et al Pulmonary injury follows systemic inflammatory reaction in infrarenal aortic surgery. Crit Care Med. 2004;32:1170-7.

112. Boldt J, Ducke M, Kumle B, Papsdorf M, Zurmeyer EL. Influence of different volume replacement strategies on inflammation and endothelial activation in the elderly undergoing major abdominal surgery. [Retraction in Intensive Care Med. 2011:37:1231; PMID: 21604012]. Intensive Care Med. 2004;30:416-22.

113. Sperry JL, Friese RS, Frankel HL, West MA, Cuschieri J, Moore EE, et al. Male gender is associated with excessive IL-6 expression following severe injury. J Trauma. 2008;64:572-8.

114. van Till JWO, van Veen SQ, den Broeder V, Bresser $P$, Lutter $R$, Out TA, et al. Compartmental apoptosis and neutrophil accumulation in severe peritonitis. J Surg Res. 2010;164:321-8.

115. Chen ZY, Qi QH. Study for effect of kangyanling on cytokine and C-reactive protein in patients of systemic inflammatory reaction syndrome and multi-organ dysfunction syndrome after abdominal surgery. Zhongguo Zhong Xi Yi Jie He Za Zhi. 2001;21:102-4
116. Matsuno N, Ikeda T, Ikeda K, Hama K, Iwamoto H, Uchiyama M, et al Changes of cytokines in direct endotoxin adsorption treatment on postoperative multiple organ failure. Ther Apher. 2001;5:36-9.

117. Schmidt SC, Hamann S, Langrehr JM, Hoflich C, Mittler J, Jacob D, et al. Preoperative high-dose steroid administration attenuates the surgical stress response following liver resection: results of a prospective randomized study. J Hepatobiliary Pancreat Surg. 2007;14:484-92.

118. Schwarz A, Bolke E, Peiper M, Schulte am Esch J, Steinbach G, van Griensven $M$, et al. Inflammatory peritoneal reaction after perforated appendicitis: continuous peritoneal lavage versus non lavage. Eur J Med Res. 2007;12:200-5

119. Bakker OJ, van Santvoort HC, van Brunschot S, Geskus RB, Besselink MG, Bollen TL, et al. Endoscopic transgastric vs surgical necrosectomy for infected necrotizing pancreatitis: a randomized trial. JAMA. 2012;307:1053-61.

120. Schietroma M, Piccione F, Carlei F, Clementi M, Bianchi Z, de Vita F, et al. Peritonitis from perforated appendicitis: stress response after laparoscopic or open treatment. Am Surg. 2012;78:582-90.

121. Schietroma M, Piccione F, Carlei F, Sista F, Cecilia EM, Amicucci G. Peritonitis from perforated peptic ulcer and immune response. J Invest Surg. 2013;26:294-304

122. Sista F, Schietroma M, Santis GD, Mattei A, Cecilia EM, Piccione F, et al. Systemic inflammation and immune response after laparotomy vs laparoscopy in patients with acute cholecystitis, complicated by peritonitis. World J Gastrointest Surg. 2013;5:73-82.

123. Kirkpatrick AW, Roberts DJ, Faris PD, Ball CG, Kubes $P$, Tiruta $C$, et al. Active negative pressure peritoneal therapy after abbreviated laparotomy: the intraperitoneal vacuum randomized controlled trial. Ann Surg. 2015;262:38-46.

124. Guo W, Soltesz V, Ding JW, Willen R, Liu X, Andersson R, et al. Abdominal rubber drain piece aggravates intra-abdominal sepsis in the rat. Eur J Clin Invest. 1994;24:540-7.

125. Walley KR, Lukacs NW, Standiford TJ, Strieter RM, Kunkel SL. Balance of inflammatory cytokines related to severity and mortality of murine sepsis. Infect Immun. 1996:64:4733-8.

126. Lane JS, Todd KE, Lewis MP, Gloor B, Ashley SW, Reber HA, et al. Interleukin-10 reduces the systemic inflammatory response in a murine model of intestinal ischemia/reperfusion. Surgery. 1997;122:288-94.

127. Rongione AJ, Kusske AM, Ashley SW, Reber HA, MCFadden DW. Interleukin-10 prevents early cytokine release in severe intraabdominal infection and sepsis. J Surg Res. 1997;70:107-12.

128. Wickel DJ, Cheadle WG, Mercer-Jones MA, Garrison RN. Poor outcome from peritonitis is caused by disease acuity and organ failure, not recurrent peritoneal infection. Ann Surg. 1997;225:744-53. discussion 753-746.

129. Bathe OF, Chow AW, Phang PT. Splanchnic origin of cytokines in a porcine model of mesenteric ischemia-reperfusion. Surgery. 1998;123:79-88.

130. Lawlor DK, Brock RW, Harris KA, Potter RF. Cytokines contribute to early hepatic parenchymal injury and microvascular dysfunction after bilateral hindlimb ischemia. J Vasc Surg. 1999;30:533-41.

131. Martineau L, Shek PN. Peritoneal cytokine concentrations and survival outcome in an experimental bacterial infusion model of peritonitis. Crit Care Med. 2000;28:788-94.

132. Knoferl MW, Diodato MD, Schwacha MG, Cioffi WG, Bland Kl, Chaudry IH. Cyclooxygenase-2-mediated regulation of Kupffer cell interleukin-6 production following trauma-hemorrhage and subsequent sepsis. Shock. 2001;16:479-83.

133. Yao V, Cooper D, McCauley R, Platell C, Hall J. Bacterial translocation in a non-lethal rat model of peritonitis. Colorectal Dis. 2001:3:338-44.

134. Oda J, Ivatury RR, Blocher CR, Malhotra AJ, Sugerman HJ. Amplified cytokine response and lung injury by sequential hemorrhagic shock and abdominal compartment syndrome in a laboratory model of ischemia-reperfusion. J Trauma. 2002;52:625-31. discussion 632.

135. Rezende-Neto JB, Moore EE, Melo de Andrade MV, Teixeira MM, Lisboa FA, Arantes RM, et al. Systemic inflammatory response secondary to abdominal compartment syndrome: stage for multiple organ failure. J Trauma. 2002;53:1121-8.

136. van Griensven M, Kuzu M, Breddin M, Bottcher F, Krettek C, Pape HC, et al. Polymicrobial sepsis induces organ changes due to granulocyte adhesion in a murine two hit model of trauma. Exp Toxicol Pathol. 2002;54:203-9.

137. Ding LA, Li JS. Effects of glutamine on intestinal permeability and bacterial translocation in TPN-rats with endotoxemia. World J Gastroenterol. 2003:9:1327-32. 
138. Ono S, Ueno C, Seki S, Matsumoto A, Mochizuki H. Interleukin-12 and -18 induce severe liver injury in mice recovered from peritonitis after sublethal endotoxin challenge. Surgery. 2003;134:92-100.

139. Rezende-Neto JB, Moore EE, Masuno T, Moore PK, Johnson JL, Sheppard FR, et al. The abdominal compartment syndrome as a second insult during systemic neutrophil priming provokes multiple organ injury. Shock. 2003;20:303-8

140. Welborn 3rd MB, Moldawer LL, Seeger JM, Minter RM, Huber TS. Role of endogenous interleukin-10 in local and distant organ injury after visceral ischemia-reperfusion. Shock. 2003;20:35-40.

141. Deitch EA, Forsythe R, Anjaria D, Livingston DH, Lu Q, Xu DZ, et al. The role of lymph factors in lung injury, bone marrow suppression, and endothelial cell dysfunction in a primate model of trauma-hemorrhagic shock. Shock. 2004;22:221-8

142. Jarrar D, Song GY, Kuebler JF, Rue LW, Bland Kl, Chaudry $\|_{H}$. The effect of inhibition of a major cell signaling pathway following trauma hemorrhage on hepatic injury and interleukin 6 levels. Arch Surg. 2004;139:896-901.

143. Hildebrand F, Pape HC, Harwood P, Muller K, Hoevel P, Putz C, et al. Role of adhesion molecule ICAM in the pathogenesis of polymicrobial sepsis. Exp Toxicol Pathol. 2005;56:281-90.

144. Frink M, Hsieh YC, Hu S, Hsieh CH, Pape HC, Choudhry MA, et al. Mechanism of salutary effects of finasteride on post-traumatic immune/inflammatory response: upregulation of estradiol synthesis. Ann Surg. 2007;246:836-43.

145. Kiank C, Entleutner M, Furll B, Westerholt A, Heidecke CD, Schutt C. Stress-induced immune conditioning affects the course of experimental peritonitis. Shock. 2007;27:305-11

146. Pimenta MBP, Aguilar-Nascimento JE, Martins DC, Silva DR, Bacelo KL, Bocchese IC, et al. The intestinal tract as the major source of interleukin 6 production during abdominal aortic clamping and hind limb ischaemiareperfusion injury. Acta Cir Bras. 2007;22:34-9.

147. Shimizu T, Yu HP, Hsieh YC, Choudhry MA, Suzuki T, Bland Kl, et al. Flutamide attenuates pro-inflammatory cytokine production and hepatic injury following trauma-hemorrhage via estrogen receptor-related pathway. Ann Surg. 2007;245:297-304.

148. Hsieh CH, Frink M, Hsieh YC, Kan WH, Hsu JT, Schwacha MG, et al. The role of MIP-1 alpha in the development of systemic inflammatory response and organ injury following trauma hemorrhage. J Immunol. 2008;181:2806-12.

149. Kan W-H, Hsu J-T, Schwacha MG, Choudhry MA, Raju R, Bland Kl, et al. Selective inhibition of iNOS attenuates trauma-hemorrhage/resuscitationinduced hepatic injury. J Appl Physiol. 2008;105:1076-82.

150. Kan WH, Hsieh CH, Schwacha MG, Choudhry MA, Raju R, Bland Kl, et al. Flutamide protects against trauma-hemorrhage-induced liver injury via attenuation of the inflammatory response, oxidative stress, and apopotosis J Appl Physiol. 2008;105:595-602.

151. Teke Z, Sacar S, Yenisey C, Atalay AO, Kavak T, Erdem E. Role of activated protein $C$ on wound healing process in left colonic anastomoses in the presence of intra-abdominal sepsis induced by cecal ligation and puncture: an experimental study in the rat. World J Surg. 2008;32:2434-43.

152. Kiris I, Narin C, Gulmen S, Yilmaz N, Sutcu R, Kapucuoglu N. Endothelin receptor antagonism by tezosentan attenuates lung injury induced by aortic ischemia-reperfusion. Ann Vasc Surg. 2009:23:382-91.

153. Liu C, Wu Q, Li Q, Liu D, Su H, Shen N, et al. Mesenteric lymphatic ducts ligation decreases the degree of gut-induced lung injury in a portal vein occlusion and reperfusion canine model. J Surg Res. 2009;154:45-50.

154. Hendriks T, Bleichrodt RP, Lomme RMLM, De Man BM, van Goor H, Buyne OR. Peritoneal cytokines predict mortality after surgical treatment of secondary peritonitis in the rat. J Am Coll Surg. 2010;211:263-70.

155. Shah SK, Jimenez F, Walker PA, Aroom KR, Xue H, Feeley TD, et al. A novel mechanism for neutrophil priming in trauma: potential role of peritoneal fluid. Surgery. 2010;148:263-70.

156. Wang P, Gong G, Li Y, Li J. Hydroxyethyl starch 130/0.4 augments healing of colonic anastomosis in a rat model of peritonitis. Am J Surg. 2010;199:232-9.

157. Zou L, Feng Y, Chen YJ, Si R, Shen S, Zhou Q, et al. Toll-like receptor 2 plays a critical role in cardiac dysfunction during polymicrobial sepsis. Crit Care Med. 2010;38:1335-42.

158. Kubiak BD, Albert SP, Gatto LA, Vieau CJ, Roy SK, Snyder KP, et al. A clinically applicable porcine model of septic and ischemia/reperfusion-induced shock and multiple organ injury. J Surg Res. 2011;166:e59-69.

159. Fernandes ES, Liang L, Smillie SJ, Kaiser F, Purcell R, Rivett DW, et al. TRPV1 deletion enhances local inflammation and accelerates the onset of systemic inflammatory response syndrome. J Immunol. 2012;188:5741-51.
160. He GZ, Zhou KG, Zhang R, Wang YK, Chen XF. Impact of intestinal ischemia/ reperfusion and lymph drainage on distant organs in rats. World $J$ Gastroenterol. 2012;18:7271-8.

161. Jiang H, Huang Y, Xu H, Hu R, Li QF. Inhibition of hypoxia inducible factor1alpha ameliorates lung injury induced by trauma and hemorrhagic shock in rats. Acta Pharmacol Sin. 2012;33:635-43.

162. Jung E, Perrone EE, Liang Z, Breed ER, Dominguez JA, Clark AT, et al. Cecal ligation and puncture followed by methicillin-resistant Staphylococcus aureus pneumonia increases mortality in mice and blunts production of local and systemic cytokines. Shock. 2012;37:85-94.

163. Shah SK, Jimenez F, Walker PA, Xue H, Feeley TD, Uray KS, et al. Peritoneal fluid: a potential mechanism of systemic neutrophil priming in experimental intra-abdominal sepsis. Am J Surg. 2012;203:211-6.

164. Gui H, Sun Y, Luo ZM, Su DF, Dai SM, Liu X. Cannabinoid receptor 2 protects against acute experimental sepsis in mice. Mediators Inflamm. 2013;2013:741303.

165. Hirano Y, Takeuchi H, Suda K, Hagiwara T, Miyasho T, Kawamura Y, et al. (Pro)renin receptor blocker improves survival of rats with sepsis. J Surg Res. 2014:186:269-77.

166. Hsu JT, Yeh HC, Chen TH, Kuo CJ, Lin CJ, Chiang KC, et al. Role of Akt/HO-1 pathway in estrogen-mediated attenuation of trauma-hemorrhage-induced lung injury. J Surg Res. 2013;182:319-25.

167. Khailova L, Frank DN, Dominguez JA, Wischmeyer PE. Probiotic administration reduces mortality and improves intestinal epithelial homeostasis in experimental sepsis. Anesthesiology. 2013;119:166-77.

168. Zheng Y, Yang Y, Li Y, Xu L, Wang Y, Guo Z, et al. Ephedrine hydrochloride inhibits $P G N$-induced inflammatory responses by promoting $\mathrm{IL}-10$ production and decreasing proinflammatory cytokine secretion via the PI3K/Akt/GSK3beta pathway. Cell Mol Immunol. 2013;10:330-7.

169. Zou L, Feng Y, Li Y, Zhang M, Chen C, Cai J, et al. Complement factor B is the downstream effector of TLRs and plays an important role in a mouse model of severe sepsis. J Immunol. 2013;191:5625-35.

170. Khailova L, Petrie B, Baird CH, Dominguez J, Wischmeyer P. Lactobacillus longum rhamnosus $G$ G and Bifidobacterium attenuate lung injury and inflammatory response in experimental sepsis. PLoS One. 2014;9, e97861.

171. Eskandari MK, Bolgos G, Miller C, Nguyen DT, DeForge LE, Remick DG. Antitumor necrosis factor antibody therapy fails to prevent lethality after cecal ligation and puncture or endotoxemia. J Immunol. 1992;148:2724-30.

172. Remick D, Manohar P, Bolgos G, Rodriguez J, Moldawer L, Wollenberg G. Blockade of tumor necrosis factor reduces lipopolysaccharide lethality, but not the lethality of cecal ligation and puncture. Shock. 1995;4:89-95.

173. Angele MK, Wichmann MW, Ayala A, Cioffi WG, Chaudry IH. Testosterone receptor blockade after hemorrhage in males. Restoration of the depressed immune functions and improved survival following subsequent sepsis. Arch Surg. 1997;132:1207-14.

174. Angele MK, Catania RA, Ayala A, Cioffi WG, Bland Kl, Chaudry IH. Dehydroepiandrosterone: an inexpensive steroid hormone that decreases the mortality due to sepsis following trauma-induced hemorrhage. Arch Surg. 1998;133:1281-8.

175. Hogaboam CM, Steinhauser ML, Schock H, Lukacs N, Strieter RM, Standiford $T$, et al. Therapeutic effects of nitric oxide inhibition during experimental fecal peritonitis: role of interleukin-10 and monocyte chemoattractant protein 1. Infect Immun. 1998;66:650-5.

176. Villa P, Shaklee CL, Meazza C, Agnello D, Ghezzi P, Senaldi G. Granulocyte colony-stimulating factor and antibiotics in the prophylaxis of a murine model of polymicrobial peritonitis and sepsis. J Infect Dis. 1998;178:471-7.

177. Balague C, Targarona EM, Pujol M, Filella X, Espert JJ, Trias M. Peritoneal response to a septic challenge. Comparison between open laparotomy, pneumoperitoneum laparoscopy, and wall lift laparoscopy. Surg Endosc. 1999:13:792-6.

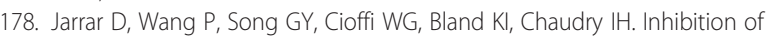
tyrosine kinase signaling after trauma-hemorrhage: a novel approach for improving organ function and decreasing susceptibility to subsequent sepsis. Ann Surg. 2000;231:399-407.

179. Oberbeck R, Dahlweid M, Koch R, van Griensven M, Emmendorfer A, Tscherne $H$, et al. Dehydroepiandrosterone decreases mortality rate and improves cellular immune function during polymicrobial sepsis. Crit Care Med. 2001;29:380-4.

180. Bauhofer A, Stinner B, Kohlert F, Reckzeh B, Lorenz W, Celik I. Granulocyte colony-stimulating factor but not peritoneal lavage increases survival rate after experimental abdominal contamination and infection. Br J Surg. 2002;89:1457-64. 
181. Pross M, Mantke R, Kunz D, Reinheckel T, Halangk W, Lippert H, et al. Reduced neutrophil sequestration in lung tissue after laparoscopic lavage in a rat peritonitis model. World J Surg. 2002;26:49-53.

182. Kuhn R, Schubert D, Tautenhahn J, Nestler G, Schulz HU, Bartelmann M, et al. Effect of intraperitoneal application of an endotoxin inhibitor on survival time in a laparoscopic model of peritonitis in rats. World J Surg. 2005;29:766-70.

183. Steinberg J, Halter J, Schiller H, Gatto L, Carney D, Lee HM, et al. Chemically modified tetracycline prevents the development of septic shock and acute respiratory distress syndrome in a clinically applicable porcine model. Shock. 2005;24:348-56.

184. Bruhn A, Verdant C, Vercruysse V, Su F, Vray B, Vincent JL. Effects of dexamethasone on macrophage migration inhibitory factor production in sepsis. Shock. 2006;26:169-73.

185. Suzuki T, Shimizu T, Szalay L, Choudhry MA, Rue 3rd LW, Bland Kl, et al. Androstenediol ameliorates alterations in immune cells cytokine production capacity in a two-hit model of trauma-hemorrhage and sepsis. Cytokine. 2006;34:76-84

186. Yang R, Harada T, Mollen KP, Prince JM, Levy RM, Englert JA, et al. AntiHMGB1 neutralizing antibody ameliorates gut barrier dysfunction and improves survival after hemorrhagic shock. Mol Med. 2006;12:105-14.

187. Ozen IO, Ekingen G, Taslipinar MY, Bukan N, Demirogullari B, Karabulut R, et al. Effect of melatonin on healing of colonic anastomosis in a rat model of peritonitis. Eur Surg Res. 2007;39:122-7.

188. Karakoc D, Sayek I. Effect of peritoneal lavage on TNF-alpha, IL-1beta, and IL-6 levels and mortality in intraabdominal infections. Int Surg. 2008;93:346-53.

189. Chatzimavroudis G, Pavlidis TE, Koutelidakis I, Giamarrelos-Bourboulis EJ, Atmatzidis S, Kontopoulou K, et al. CO(2) pneumoperitoneum prolongs survival in an animal model of peritonitis compared to laparotomy. J Surg Res. 2009;152:69-75.

190. Kubiak BD, Albert SP, Gatto LA, Snyder KP, Maier KG, Vieau CJ, et al. Peritoneal negative pressure therapy prevents multiple organ injury in a chronic porcine sepsis and ischemia/reperfusion model. Shock. 2010;34:525-34.

191. Yuan Y, Ren J, Wu X, Cao S, Li J. Exogenous C3 postpones complement exhaustion and confers organ protection in murine sepsis. J Surg Res. 2011;168:e87-94

192. Calisto KL, Camacho AC, Mittestainer FC, Carvalho BM, Guadagnini D, Carvalheira JB, et al. Diacerhein attenuates the inflammatory response and improves survival in a model of severe sepsis. Crit Care. 2012;16:R158.

193. Herzig DS, Guo Y, Fang G, Toliver-Kinsky TE, Sherwood ER. Therapeutic efficacy of CXCR3 blockade in an experimental model of severe sepsis. Crit Care. 2012;16:R168.

194. Peng ZY, Wang HZ, Srisawat N, Wen X, Rimmele T, Bishop J, et al. Bactericidal antibiotics temporarily increase inflammation and worsen acute kidney injury in experimental sepsis. Crit Care Med. 2012;40:538-43.

195. Bangash MN, Patel NSA, Benetti E, Collino M, Hinds CJ, Thiemermann C, et al. Dopexamine can attenuate the inflammatory response and protect against organ injury in the absence of significant effects on hemodynamics or regional microvascular flow. Crit Care. 2013;17:R57.

196. Chen F, Fan XH, Wu YP, Zhu JL, Wang F, Bo LL, et al. Resolvin D1 improves survival in experimental sepsis through reducing bacterial load and preventing excessive activation of inflammatory response. Eur J Clin Microbiol Infect Dis. 2014:33:457-64.

197. da Silva JBNF, de Oliveira SKM, Campos IA, de Carvalho-Junior CHR, Coutinho TDC, Silva TG. Propionibacterium acnes-killed attenuates the inflammatory response and protects mice from sepsis by modulating inflammatory factors. Braz J Infect Dis. 2013;17:20-6.

198. Du MH, Luo HM, Hu S, Lv Y, Lin ZL, Ma L. Electroacupuncture improves gut barrier dysfunction in prolonged hemorrhagic shock rats through vagus anti-inflammatory mechanism. World J Gastroenterol. 2013:19:5988-99.

199. Fujimura N, Obara H, Suda K, Takeuchi H, Miyasho T, Kawasako K, et al. Neutrophil elastase inhibitor improves survival rate after ischemia reperfusion injury caused by supravisceral aortic clamping in rats. J Surg Res. 2013:180:e31-6.

200. Teixeira-da-Cunha MG, Gomes RN, Roehrs N, Bozza FA, Prescott SM, Stafforini D, et al. Bacterial clearance is improved in septic mice by platelet-activating factor-acetylhydrolase (PAF-AH) administration. PLoS One. 2013;8, e74567.
201. Theobaldo MC, Llimona F, Petroni RC, Rios EC, Velasco IT, Soriano FG. Hypertonic saline solution drives neutrophil from bystander organ to infectious site in polymicrobial sepsis: a cecal ligation and puncture model. PLoS One. 2013;8, e74369.

202. Matsuda A, Yang W, Jacob A, Aziz M, Matsuo S, Matsutani T, et al. FK866, a visfatin inhibitor, protects against acute lung injury after intestinal ischemiareperfusion in mice via NF-k B pathway. Ann Surg. 2014;259:1007-17.

203. Simmons JD, Lee YL, Mulekar S, Kuck JL, Brevard SB, Gonzalez RP, et al. Elevated levels of plasma mitochondrial DNA DAMPs are linked to clinical outcome in severely injured human subjects. Ann Surg. 2013;258:591-6. discussion 596-598.

204. Mi Q, Constantine G, Ziraldo C, Solovyev A, Torres A, Namas R, et al. A dynamic view of trauma/hemorrhage-induced inflammation in mice: principal drivers and networks. PLoS One. 2011;6, e19424.

205. Nieman G, Brown D, Sarkar J, Kubiak B, Ziraldo C, Dutta-Moscato J, et al. A two-compartment mathematical model of endotoxin-induced inflammatory and physiologic alterations in swine. Crit Care Med. 2012;40:1052-63.

206. Sartelli M, Viale P, Catena F, Ansaloni L, Moore E, Malangoni M, et al. 2013 WSES guidelines for management of intra-abdominal infections. World J Emerg Surg. 2013;8:3

\section{Submit your next manuscript to BioMed Central and take full advantage of:}

- Convenient online submission

- Thorough peer review

- No space constraints or color figure charges

- Immediate publication on acceptance

- Inclusion in PubMed, CAS, Scopus and Google Scholar

- Research which is freely available for redistribution 